\title{
CONDITIONAL RELEASE OF AN ACCUSED IN JAPAN
}

\author{
Shigemitsu Dando $†$ and Hiroshi Tamiya $\ddagger$
}

\section{Detention}

Since the physical restraint of an accused ${ }^{1}$ prior to and during trial affects so fundamental a human right as personal freedom, such restraint should be permissible only in those limited cases where it is absolutely necessary for the investigation of a crime or for the conduct of trial. In this belief Japan has numerous statutory provisions regulating the physical restraint of an accused. ${ }^{2}$

To begin with an accused may not be apprehended for detention except upon warrant issued by a competent judicial officer. ${ }^{3}$ Detention is justified only when there are reasonable grounds to suspect that the accused has committed a crime and when, in addition, his case falls

\section{† Professor, Tokyo University.}

¥ Assistant Professor, Hokkaido University.

1 For purposes of this Article, "accused" will be used as including a suspect.

2 One might say that there are three ways to protect the right of an accused from abuse through physical restraint: prevention, sanction and compensation. Hirano, Guaranty of Personal Liberty, 64 KoKKA GAKKAI ZASSI (Journal of the Association of Political and Social Sciences) 135 (1950). Preventive methods will be described in the following paragraphs of text. As to sanction, the PENAL Code (JAPAN, Penal CODE (Ministry of Justice ed. 1957) [hereinafter cited as PENAL CODE]) punishes abuse of authority by a public officer, art. 193; illegal arrest and confinement by a person performing or assisting in judicial, prosecutorial or police functions, art 194; and mistreatment by such a person, art. 195 . If, in a case in which complaint or accusation is made of any of these offenses, the complainant or accuser is dissatisfied with the disposition made by a public prosecutor, he may apply to a district court to secure a trial of his complaint. JAPAN, CODE OF CRIMINAL ProceduRE art. 262 (Ministry of Justice ed. 1957) [hereinafter cited as CoDE]. Finally, as regards compensation, article 40 of JAPAN, Const., provides: "Any person, in case he is acquitted after he has been arrested or detained, may sue the State for redress as provided by law." And according to the Criminal Compensation Law, Japan Law No. 1, 1950, as amended, Law No. 208, 1952, as amended, Law No. 68, 1953, the accused has a claim against the Government for compensation for such arrest or detention, not only in case of acquittal as not guilty but also in the event of dismissal, if there exists sufficient reason to believe that a decision of not guilty would upon full trial have been rendered. Furthermore, under the Regulation for Suspect's Compensation, Ministry of Justice Instruction No. 1, 1957, a suspect, if detained during investigation, may claim compensation if the public prosecutor decides not to prosecute. In this connection it is also to be noted that the number of days of pre-judgment detention are deducted from a subsequent sentence. PENAL CODE art. 21; CODE art. 495.

3 JAPAN, CoNsT. art. 33. For certain exceptions, such as arrest during the commission of an offense, see CODE arts. 211-13. Warrants may issue only upon reasonable cause to suspect that the accused has committed an offense; and no warrant shall issue in case the judge "deems that there is evidently no necessity for arresting the suspect." CODE art. 199, para. 2. 
under one of the following provisions: (1) he has no established residence; (2) there are reasonable grounds to suspect that he may destroy evidence; or (3) he has escaped, or there are reasonable grounds to suspect that he may escape. ${ }^{4}$ In any event there are limitations on the permissible duration of detention: normally detention for investigation shall not exceed ten days ${ }^{5}$ and, after prosecution has been instituted, a two month limitation applies. ${ }^{6}$ Even within these limits, the court is required to rescind the detention upon the request of the accused or other person, or ex officio, when the grounds or necessity for detention have ceased to exist. ${ }^{7}$ And it is provided that when physical restraint "has been effected for an unreasonably long period, the court shall . . . rescind the detention or allow the release on bail." 8 To secure these substantive rights, and pursuant to the Japanese constitutional provision that no person shall "be detained without adequate cause; and upon demand of any person such cause must be immediately shown in open court in his presence and the presence of his counsel," 9 provision has been made to permit the accused, defense counsel, legal representative, or any of a number of specified relatives of the accused who is under detention, to request the court to indicate the reason for his custody. ${ }^{10}$ The accused may appeal to a higher court for reversal of a ruling or order of detention. ${ }^{11}$ And, finally, there is a habeas corpus act of the Anglo-American type. ${ }^{12}$

But since these controls are not alone enough to protect fully the rights of an accused, Japan has provided for two types of conditional release: bail and suspension of the execution of detention.

4 CODE art. 60. An exception is made with respect to cases involving certain minor crimes, in which case only the first provision (no established residence) applies. CODE art. 60 , para. 3. Detention at the stage of investigation is regulated in the same manner. CODE art. 207.

5 CODE art. 208, para. 1. Where a judge finds that "unavoidable circumstances" exist, detention during investigation may be extended ten or, in the case of certain specified crimes, fifteen days. CoDE arts. 208, para. 2, 208-2.

${ }^{8}$ Cone art. 60, para. 2. Provision in the nature of limited exceptions is there made for instances of special necessity.

7 CODE art. 87.

8 CODE art. 91.

9 JAPAN, CoNst. art. 34. For a discussion of this provision of the Constitution see 1 Hogakukyorat, The Constitution of Japan Annotated 613 (1953); Mryazawa, The Constitution of Japan 293 (1955).

10 CODE arts. 82-87.

11 Code arts. 420, 429.

12 Dando, On the Habeas Corpus Act, in The Interrelation Between Criminal LAW AND CRIMINAL Procedure 232 (1950); Kawahara, Scope and Procedure in Habeas Corpus Act, in A Treatise on the Fundamental HuMan Rights 72, 73 (1957). See generally Hrrano, Criminal Procedure 104 (1958); Idei, A Report on the Preliminary Examination in the United States, in 2 THEORY AND REALITY of CRIMINal LAW 63 (1951). 


\section{BAIL}

\section{Bail as a Matter of Right}

The bail system in Japan dates back to the Code of Criminal Procedure of 1880,13 which provided that "a judge of the preliminary examination (juge d' instruction) may, at any time, release on bail upon request an accused for whom the warrant of detention or custody was executed, making him present a deed promising to appear when summoned, after hearing the opinion of a public prosecutor." 14 The Code of Criminal Procedure of 1922 provided more concisely: "The court shall issue a ruling when a request of bail is made, after hearing the opinion of a public prosecutor." ${ }^{15}$ But though bail itself has been recognized since the time of the modernization of criminal procedure, under these early codes the granting of conditional release was left solely to the discretion of the court. It was epoch-making, therefore, when the new Code of Criminal Procedure of 1948 made bail in a large class of cases a matter of right. The Code provides, with express exceptions: "When the request for release on bail has been made, it must be allowed. . . ."16 This change, in its recognition of fundamental human rights and the accusatorial principle, points to a great progress in Japanese criminal procedure.

However, attention should be drawn to the fact that the availability of bail as a matter of right, severely limited by statutory exceptions, is becoming more and more nominal through the progressive legislative tendency to widen those exceptions. ${ }^{17}$ Currently bail need not be granted: (1) where the accused is charged with an offense punishable by death or by imprisonment for a minimum period of not less than one year; ${ }^{18}$ (2) where his name or residence is unknown; (3) where he has previously been convicted of an offense punishable by death or by imprisonment for a maximum period of more than ten years; (4) where he has habitually committed an offense punishable by imprisonment for a maximum period of three years or more; (5) where there are reasonable grounds to suspect that he may destroy evidence;

13 Our criminal procedure may be said to have been modernized by this code. See also art. 150 of the Code of Criminal Procedure of 1890 . Though the provision governing bail was found in the chapter on preliminary proceeding in both of these codes, it was doubtless applied to the whole trial proceedings. See 1 Tomita, OUTlines of Cruminal Procedure 608 (4th ed. 1913); Toyoshima, A New Treatise on Criminal Procedure 337 (1910).

14 Code of Criminal Procedure art. 210 (1880).

15 Code of Criminal Procedure art. 116 (1922).

16 CoDe art. 89.

17 See note 76 infra.

18 As to this first exception, see Hiraide, Bail, 84 JurIst 36 (1955). Hiraide emphasizes the influence upon society resulting from the release of such an accused. 
(6) where there are reasonable grounds to suspect that he may threaten or cause injury to the person or property of the victim of the offense charged, to some other person who is considered to have knowledge necessary for the trial of the offense, or to a relative of such person. ${ }^{19}$

It will be seen that these exceptions fall by their reasons into three categories corresponding to three potential justifications for physical restraint of an accused. The first pair of exceptions involve instances where the danger of non-appearance for subsequent prosecution is too strong to be obviated by pecuniary coercion; they intend to secure the accused's presence at trial. ${ }^{20}$ The third and fourth, having to do with the accused's past record, are designed to assure the safety feelings of society at large by minimizing the likelihood of the repetition of criminal acts by previous offenders. ${ }^{21}$ The sixth exception, concerning cases of possible threats or injury to the victim of the offense charged or to potential witnesses, may also serve this function of eradicating social uneasiness. Some think that this item, added by the 1953 revision to prevent the risk of the accused's paying a "visit of thanks" (oreimairi), was intended to prevent the commission of crimes of violence. $^{22}$ But the prevailing opinion takes it instead, along with the fifth statutory exception, as provision for an instance of still another category: where it is feared that the accused will suppress evidence. ${ }^{23}$ In this connection it should be remembered that the institution of posting bail is by its nature intended only to secure the appearance of an accused for trial. Thus, in Germany, while the accused may be detained either by reason of the danger of his suppressing evidence or of his escaping, bail is permissible only where custody is effected on the ground of danger of escape; ${ }^{24}$ whereas, in the Anglo-American law which allows detention only where the accused threatens to take flight, ${ }^{25}$ the court must as a rule release him on bail. In Japanese law, grounds

19 CODE art. 89.

$20 \mathrm{It}$ is reasonable to exclude bail as a matter of right in cases of offenses punishable with the death penalty or with life imprisonment. But in the writer's opinion the legislature went too far when by amendment in 1953 it included in this category all offenses punishable with imprisonment of more than one year. See Yoshida, Compulsory Measures, in Revision of THE CODE of CRIMINAL Procedure (SPECIAL Issue of Journal of CRIMINAL LAw) 45 (1953); Takada, On the Revision of the Code of Criminal Procedure, in id. at 224. Contra, Yokor, OUthrnes of THE REvised Code of Criminal Procedure 33 (1953).

21 Professor Hirano is of the opinion that these are the cases where the danger of escape is very strong. HrRano, op. cit. supra note 12 , at 164 .

22 Uematsu, Paying a Visit of "Thanks" and the Bail, 83 Court Decrsion Trmes (Hanrei Jiho) 2226 (1956).

23 Hirano, op. cit. supra note 12, at 164. Nakajima, Some Problems on DeTENTION AND BAIL 359 (Report of Judicial Research, vol. 8, no. 9, 1957).

24 St. P.O. § 117.

25 See Hetzel, Die Untersuchungshaft NaCH DeUTSCHEM, oEsterReichischem, FRANZOESISCHEM UND ENGLISCHEM RECHTE, Str. Abh. H. 26 (1899). See also Foote, Foreword: Comment on the New York Bail Study, 106 U. PA. L. REv. 685, 686 (1958). 
of detention include both the risk of escape and of suppression of evidence. ${ }^{26}$ Therefore the chance that the accused will destroy evidence is added as a specific limitation upon the right to conditional release.

\section{Bail as a Matter of Discretion}

Even where these exceptions apply to bar bail as of right, the court may within its discretion release the accused on bail. Instances of discretionary release are less frequent than those where bail is granted as a matter of right, but the former are not to be neglected. The scope of discretion varies widely, however, among cases which fall within the six different statutory exceptions to bail as of right: where the grounds put forward for refusal are a probability of the destruction of evidence or the injury of the victim or a witness, less discretion is permitted the court than in cases where the grounds involve the accused's past record or the nature of the offense presently charged. ${ }^{27}$ And where the court does not know the name or residence of the accused, it may release him only if it knows how to communicate with him.

The courts' discretion to grant bail is further implemented by article 90 of the Code of Criminal Procedure: "A court may, if it deems it proper, grant release on bail ex officio." Thus, where because of illiteracy or ignorance of the law (especially probable when an accused has no counsel to defend him), the accused fails to request release, the court may nevertheless grant release on bail. And where further restraint is likely to endanger the life of an accused because of serious illness, or in other special circumstances such as the breaking out of a fire or contagious disease in the jail, a court might find it appropriate to release him despite countervailing considerations, even though he does not request it. But it is arguable that an accused will be less likely to observe the terms of his release where he is released in spite of, and at times even against, his will. ${ }^{28}$ Finally, note has already been made of the somewhat unique provision of the new Code of Criminal Procedure which demands that when a court finds that there has been effected a detention of unreasonably long duration, the court must

26 See text accompanying note 4 supra.

27 "Indeed it is not proper to release the accused on bail when there is a danger of destroying evidence, but we can not say definitely that it is quite impossible." Midorikawa, Compulsory Measures in Criminal Procedure 130 (1956). Midorikawa argues that by fixing bail at a sufficiently high figure, the accused can be prevented from destroying evidence; also that any conditions considered proper to that purpose can be imposed. See text above note 47 infra.

28 Dando, Problems of Conditional Release Prior to and During Trial, U.N. Seminar on the Protection of Human Rights in Criminal Law and Procedure, Working Paper B 16-17 (1958). 
either rescind the detention or allow release on bail. ${ }^{29}$ This we call a mandatory bail in the sense that the court must order release if it finds that the prescribed condition exists. ${ }^{30}$

\section{Stages in the Proceedings}

In Japan conditional release as of right is limited to the period after investigation and before sentence: the court may in no event set the accused at liberty on bail during investigation, ${ }^{31}$ and by express provision of the Code of Criminal Procedure the accused is no longer entitled to bail as a matter of right after rendition of a sentence of imprisonment or graver punishment. ${ }^{32}$ The first of these provisions is said to be justified both on grounds of the brevity of the time involved ${ }^{33}$ and the greater likelihood that the accused will destroy evidence; the second on the grounds that the presumption of innocence is less applicable and that the probability of the accused's taking flight rather than appearing for execution of his sentence is more to be feared. But it is to be noted that the accused is not required to appear before the appellate court on appeal from his conviction. ${ }^{34}$

\section{Conditions}

The first, necessary, condition to release on bail is the fixing of the amount of bail money by the court. ${ }^{35}$ Bail is set in accordance with standards of consideration set forth in the Code: "The bail money shall be fixed in amount sufficient and adequate to insure the presence of the accused, taking into consideration the nature and circumstances of the offense, weight of evidence against him, his character and financial ability to give bail." 38 By considering "the nature and circumstances of the offense" the court attempts to predict the degree of likelihood of flight. By the inclusion of "weight of evidence" it can be seen that the court may properly attempt to determine probability of the accused's being guilty. As to "financial ability," the court will consider not only

29 See note 8 supra and accompanying text. It should be noted that the Japanese Constitution expressly provides that the confession of an accused made after prolonged arrest or detention shall not be admissible in evidence. JAPAN, Const. art. 38, para. 2.

30 Conditional release may also be said to be mandatory in instances where there is danger that physical restraint will result in the death of the accused or in serious impairment to his health, or where there is no other person to take care of his dependents who are in need of support.

31 CODE art. 207.

32 CODE art. 344.

33 See note 5 supra and accompanying text.

34 CoDe art. 390.

35 CoDE arts. 93, para. 1, 94, para. 1.

36 CODE art. 93, para. 2. 
the property belonging to the accused but also financial credit to which he has access. And, of course, the listed Code considerations being only exemplary, there are other circumstances that will be regarded by the court. The court will look to the accused's home environment, ${ }^{37}$ his reputation, personal career, social status, and physical and mental condition. It will consider what other, non-monetary conditions it can effectively impose. ${ }^{38}$ It is clear also that the court will not ignore prior judicial determinations in similar instances. ${ }^{30}$

Bail money should be fixed at an amount sufficient to minimize, through fear of forfeiture, the likelihood that the accused will attempt to escape prosecution. But excessive bail ought not be imposed. ${ }^{40}$ Arriving at the proper amount is, of course, a very difficult problem and demands a concrete, case by case calculation. In practice it has tended to be handled somewhat as a matter of routine. In order to ascertain better the particular circumstances which should determine a proper amount of bail for each accused, it will be necessary to develop a system of pre-bail investigation.

In granting release on bail, the court may order the accused to pay money into court before taking his leave. ${ }^{41}$ This will sometimes present a hardship since in Japan there are as yet neither public bondsmen nor professional surety companies. ${ }^{42}$ However, bail need not in all cases be pecuniary. The court may permit negotiable securities to be delivered as bail. ${ }^{43}$ Although there is no statutory limitation as to the permissible kind of negotiable securities which may be offered, those of ascertainable and stable market price, such as public loan bonds or government securities, are most desirable. The use of negotiable securities is, however, rare in practice. ${ }^{44}$ More frequently used is the method of substituting for cash payment the written undertaking of a third person. While ordinarily bail is to be paid by the accused himself, the court may permit a person other than the accused to pay it

371 Dando, Code of Criminal Procedure Annotated 188 (1950).

38 See note 47 infra and accompanying text.

39 NARAJIMA, op. cit. supra note 23, at 374 .

40 Japan does not, however, have a specific constitutional provision prohibiting excessive bail. Cf. U.S. CoNST. amend. VIII.

41 CODE art. 94, para. 1.

42 At present there is no strong demand for bondsmen inasmuch as the Japanese courts have wide discretion in setting the amount of bail and, furthermore, release may be granted upon non-pecuniary security or the written undertaking of a third person. See notes 43,46 infra and accompanying text.

43 CODE art. 94, para. 3.

44 NARAJIMA, op. cit. supra note 23, at 382; Yasumura, Bail and the Suspension of Execution of Detention, in 2 LeCTURES ON LEGAL PRACTICE (Criminal Law Section) 290 (1953). 
in whole or in part. ${ }^{45}$ And it is furthermore specifically provided that release may be granted upon the written obligation of a third party surety that the bail money will be paid upon demand. ${ }^{46}$ The court may in fact demand cash payment if and when it determines that because of a change in the surety's financial position the written undertaking is no longer sufficient to compel the appearance of the accused.

When release on bail is granted, there may be other, non-financial conditions imposed: the accused may be confined to his residence, his travel may be restricted or he may be required to make periodic appearances in court or at some other designated place. ${ }^{47}$ Such conditions are entirely optional with the court. But there are certain conditions which are considered improper: promises that the accused will not suppress evidence or injure the person or property of another, or that he will neither drink nor smoke, or that he will be on good behavior. ${ }^{48}$ Conditional release from detention is not to be used to serve the same purposes as detention itself, nor other broader purposes of criminal policy.

\section{Suspension of the Execution of Detention}

\section{History, Purpose and Functions}

There is in Japan another type of conditional liberation, suspension of the execution of detention, a method of release into the custody of a responsible third party. Suspension is peculiar to Asian law; ${ }^{49}$ known to have existed in China as early as the eighth century, ${ }^{50}$ it was then introduced into Japan where it has at various times been called "Oazuke" and "Sekifu." This system has, in its essential points, survived the modernization of Japanese criminal procedure. ${ }^{51}$ The Code of Criminal Procedure of 1880 provided: "The judge of preliminary examination (juge d'instruction) may, after hearing the opinion of a public prosecutor, entrust the accused to the charge of his relative or

45 CODE art. 94, para. 2. On the other hand, the court may of course order the accused himself to pay the amount of bail, even though another person has requested the release on bail. CODE art. 88. YASUMURA, op. cit. supra note 44, at 289 . In the event of insolvency of the accused, the person who pays his bail will ensure that the accused follow the conditions to his release; the friend will not wish to have his own money forfeited. Thus this method is an effective aspect of the bail system.

46 CoDE art. 94, para. 3.

47 CODE art. 93, para. 3.

48 The Fukuoka High Court has ruled that the condition, "the accused must be on his good behavior and must not commit another crime," is unlawful. 2 Special Report of High Court Decision 1061 (1955). Contra, MIdorikawa, op. cit. supra note 27 , at 130; Uematsu, supra note 22 , at 2226.

49 Dando, Principles of Criminal Procedure 271 (7th ed. 1958); Ono \& Dando, Chinese Code of Criminal Procedure § 115 (1938).

50 Takikawa, The History of Japanese Law 342 (1941).

61 Ono, Criminal Procedure 252 (3d ed. 1933). 
acquaintance, whether he requires the release on bail or not." ${ }_{22}$ The new Code of Criminal Procedure reads: "A court may, by means of a ruling, if it deems proper, suspend the execution of detention by entrusting the accused under detention to the charge of his relative, a protective institution and the like, or restricting his dwelling." 53

The functioning of this second, non-monetary system of release is potentially very important, especially in instances where the accused is too poor to pay bail, where for any reason it is feared that the imposition of a financial burden alone will not be sufficient to deter him from flight, where there arises an urgent necessity of immediate release such as sudden illness or a death in his family, ${ }^{54}$ where release for a short term is appropriate, or where the judge desires to release the accused during the period of investigation. Suspension, like the bail system, aims to insure the appearance of an accused at his trial; it plays perhaps a more important role than bail in the furtherance of criminal policy by minimizing the likelihood of repetition of criminal offenses. ${ }^{55}$ And by supplementing bail where the latter method is either legally unavailable or practically impossible, it enhances the opportunities of an accused to secure conditional release.

Yet in practice suspension of the execution of detention is very rarely ordered..$^{56}$ The institution was at its inception designed to function within the family unit or small local (usually rural) community; in present-day Japan delivery of the accused into the protective custody of society is less feasible. What is needed for this purpose is an increase and improvement in social welfare agencies, unfortunately not yet fully developed in Japan. ${ }^{57}$

\section{Conditions}

As a condition of suspension an accused may be placed in the protective custody of an institution or person; ${ }^{58}$ such institution or person is required to file a written undertaking that the accused will be caused to appear whenever summoned. ${ }^{59}$ However, the entrustee does not have the legal right or duty to apply force in making the accused

52 Article 219. For similar provision in subsequent codes see the code of 1890 , art. 159, and the code of 1922, art. 118.

53 CODE art. 95.

54 Yokokawa, Arrest, Detention and BaIl 159 (1958).

55 DANDo, op. cit. supra note 49, at 271 .

56 It is granted only ex officio.

57 This is one of the reasons why the court hesitates to permit the suspension of the execution of detention. NAKAJIMA, op. cit. supra note 23, at 413.

58 Cone art. 95.

59 Rules of Crminal. Procedure (Supreme Court Rules No. 32, 1948, as amended) art. 90 (Ministry of Justice ed. 1957). 
appear. The sanction for an accused's failure to report is rescission of the suspension. ${ }^{\text {B }}$ Furthermore, by express Code provision, an accused may be restricted to his residence. ${ }^{61}$ But it is arguable whether both of these conditions may be imposed at the same time. ${ }^{62}$ It is also questionable whether the court may impose conditions other than these two upon the accused. ${ }^{63}$ But it appears clear that, as with bail, a condition that the accused will not suppress evidence or commit another crime is not permissible.

IV. Reconfinement of the Accused and Forfeiture of BaIL

\section{Reconfinement}

An accused will be reconfined, (1) when bail or suspension of the execution of detention loses its effect, or (2) when the court rescinds the release. Conditional release automatically loses its effect upon the rendition of a sentence to imprisonment or graver punishment; reconfinement is then mandatory in the absence of a new ruling of bail or suspension. $^{64}$ Likewise reconfinement follows the expiration of any specific period for which detention may have been suspended.

But what is of more significance in reconfinement is the power of the court at its discretion to rescind conditional release. It is provided that the court may, upon request of a public prosecutor or ex officio, rescind release on bail or the suspension of execution of detention in any one of the following cases: (1) where the accused has without good reason failed to appear when summoned; ${ }^{65}$ (2) where the accused has escaped or there are reasonable grounds to suspect that the accused may

60 CODE art. 96, para. 1.

61 CODE art. 95.

62 Those who argue that the conditions can not be imposed at the same time, base their argument on the fact that there is no express permission to do so in that part of the Code dealing with the suspension of the execution of detention, whereas there is such express permission with respect to release on bail. CODE art. 93, para. 3. Compare I Hayashi, Essentials of Criminal Procedure 198 (1922), and Takikawa, Hiraba \& Nakabu, Code of Criminal Procedure Annotated 131 (1950), with 1 Dando, Code of Criminal Procedure Annotated 191 (1950), Nakajima, op. cit. supra note 23, at 415, TAKadA, Criminal Procedure 172 (2d ed. 1959), and Yasumura, supra note 44 , at 295.

63 Certainly one other condition that may be imposed is the duration of the release. CODE art. 98.

64 CoDE art. 343. The reason offered for this is that as a result of conviction the presumption of innocence is diminished, while the probability that the accused will attempt to escape is increased. A further reason is to be found in the apprehension that society may experience at the knowledge that there is a convicted criminal loose among them.

${ }^{65}$ The Tokyo High Court has said that, even in the event the accused is arrested or detained with regard to a second prosecution, he must inform the second prosecuting officer of his required appearance in the first proceeding. $9 \mathrm{High}$ Court $\mathrm{Re}-$ port 182 (1956). 
escape; ${ }^{66}$ (3) where the accused has destroyed evidence or there are reasonable grounds to suspect that the accused may destroy evidence; (4) where the accused has injured or attempted to injure the person or property of another ${ }^{67}$ or (5) where the accused has failed to comply with the restrictions imposed upon him by the court. ${ }^{88}$ These grounds of rescission are of course very similar to those which are provided for the denial of bail as a matter of right. Statistically it is rare that the court rescinds release; ${ }^{69}$ this is perhaps because the court will usually produce the accused, ${ }^{70}$ rather than rescind his release, when he fails or when there is apprehension that he may fail to comply with his summons without good reason. Another cause of the infrequency of rescission is that, practically speaking, the court cannot satisfactorily observe the behavior of the accused during his release. ${ }^{71}$ Under the provisions of the Code an accused has the right to appeal to a higher court from a ruling of rescission. ${ }^{\mathbf{7}}$

\section{Forfeiture of Bail}

Bail may be forfeited when conditional release is rescinded. ${ }^{73}$ It shall be forfeited when the released person against whom a sentence has

66 "That he is out of employment and lives extravagantly is very indicative that he may not long remain settled at his abode. Furthermore, as he is living on profit of a crime, we can conclude that the apprehension of escape is grave." 7 Report of Tokyo High Court Decision 266 (1956).

$67 \mathrm{It}$ is not proper to rescind release on bail merely as a penalty when the accused is found to have destroyed evidence or to have injured the body or damaged the property of the victim or other persons, since rescission is not of the nature of punishment or sanction. See NARAJIMA, op. cit. supra note 23, at 386; ONo, YokokAWA, Yokor \& Kurmoto, Code of Criminal Procedure: Pocket Commentaries 183 (1955). But such a finding may of course be deemed indicative of a probable course of similar future action. (1950).

${ }^{68}$ CodE art. 96, para. 1. See also 14 Special Report of High Court Decision 11

60 NAKAJIMA, op. cit. silpra note 23, at 388; ONo, Yokokawa, Yokor \& KURIмото, op. cit. supra note 67 , at 182 ; YoKOKAWA, op. cit. supra note 54, at 43.

70 Production is a procedure by which the accused may be apprehended and brought before the court upon a warrant of production, CODE arts. 62, 64, when, inter alia, he fails, or there is apprehension that he may fail, to appear voluntarily upon summons. CoDE art. 58, para. 2. An accused who is brought into court on a warrant of production must be released within twenty-four hours of his appearance there, unless a warrant for his detention has been issued during that interval. CoDE art. 59 .

71 ONo, YokoKaWA, Yokor \& KunIMoto, op. cit. supra note 67, at 182; Yokokawa, op. cit. supra note 54 , at 43 . As the behavior of an accused may be more effectually scrutinized by a public prosecutor or a policeman, the Code has given the prosecutor power to request the court to rescind the release. Cone art. 96.

72 CoDE art. 420 . When release on bail or suspension of execution of detention is rescinded, the accused must be put in confinement under the direction of a public prosecutor, by a public prosecutor's assistant officer, judicial police official or prison officer, who must show the accused a copy of the warrant of detention or a copy of the written ruling which has rescinded the release. CoDE art. 98, para. 1.

${ }^{73}$ CODE art. 96, para. 2. The question of forfeiture in this case is left entirely to the discretion of the court, which may order forfeiture in whole or in part or may order restitution. This flexibility is permitted in order to make provision for such 
been rendered and judgment has become final has failed without good reason to appear when called before the court for execution of the sentence. $^{74}$

\section{Some Critical Observations}

Confinement of an accused is detrimental not only as a source of physical and psychological pain but also as a grave impairment of his social activity. It humiliates the accused; it has a morally harmful effect upon him. The public interest too is adversely affected, for the state must bear the expense of maintaining him. ${ }^{75}$ Consequently, detention of an accused should be permitted only when it is absolutely necessary to the effective administration of the criminal law. Even where initial physical restraint may have been advisable, he should be released from custody whenever it is certain that his appearance before the court can be secured.

But unfortunately bail as of right in Japan is severely limited. ${ }^{76}$ As has been seen, exceptions to the right are made upon fear that the accused will tamper with evidence or will commit a different crime. It is submitted that these are not proper exceptions ${ }^{77}$ and should be abrogated. ${ }^{78}$ It is inconsistent with the accusatorial principle that a danger of suppression of evidence should constitute grounds for detention; detention on this ground might even be said to be a logical contradiction to a system of bail as a matter of right. ${ }^{79}$ The AngloAmerican system has proved to be successful although it does not recognize these exceptions. And even if, as is argued, criminal investi-

cases as those in which the accused is not himself the person paying the bail, and in which the rescission of release has been effected precisely tupon information concerning the escape of the accused offered by the person who did pay the bail money for him. In any case, moreover, the court must adjudge the degree of culpability of the accused. Note that the ruling of forfeiture must be rendered at the same time as the ruling of rescission. 5 High Court Report 1649 (1952). But see ONo, YorokAwA, YokoI \& KURIMOTo, op. cit. sippra note 67, at 184.

74 Cone art. 96, para. 3. Forfeiture is ordered only upon request by a public prosecutor, but when that officer so requests, the court is required to sequestrate the bail money. In such cases, the bail has become significant only for the purpose of execution of punishment; therefore discretion as to its disposition is left rather to the prosecutor, who is charged with the execution of punishment, than to the court. It is within the discretion of the court however, whether to order forfeiture of the whole or of only a part of the sum posted.

75 Orfield, Criminal Procedure From Arrest to Appeal 105 (1947).

76 See notes 17-26 supra and accompanying text. Particularly unfortunate in the writer's opinion was the widening of the exceptions by amendment in 1953. The amendment encountered strong opposition. See note 20 sipra.

77 For a similar view see Foote, Foreword: Comment on the New York Bail Study, 106 U. PA. L. REv. 686 (1958).

78 See Yokokawa, op. cit. supra note 54, at 201. See also Hetzer, op. cit. supra note 25 , at 23 .

78 Hirano, Guaranty of Personal Liberty, 64 Kokka GakkaI $Z_{\text {ASSI }}$ (Journal of the Association of Political and Social Sciences) 152 (1950). 
gation in Japan is somewhat more difficult than in the United States, this argument presents no justification for the denial of conditional release as of right at any time subsequent to the early, investigatory stage of criminal proceedings. Likewise, Japan must reconsider the relationship between the purposes of detention of an accused and the preventive policy of the criminal law. Although a reasonable apprehension that the accused may commit other offenses does not constitute a ground for detention itself, ${ }^{80}$ it is made a ground for barring bail as of right. ${ }^{81}$ This seems indirectly to make detention a sort of instrument of prevention. ${ }^{82}$ But there is no proper connection between mere accusation of a past offense and amenability to preventive custody; if detention is to be used to restrain those who may commit crime, it should not be limited to persons accused. So danger of an accused's engaging in criminal acts while on release should not provide any justification for denial of bail. ${ }^{83}$ The remedy for that risk should lie not in detention but in prompt trial. ${ }^{84}$

Finally, under present law bail is not permitted before the institution of prosecution. ${ }^{85}$ The reason most frequently given is that detention during that time is of only brief duration. But actually the period prior to prosecution is by no means short: detention may lawfully be extended to twenty, and in some cases to twenty-five days. ${ }^{86}$ If release on bail is not then granted, enforcement officials will tend to utilize detention as a means for subjecting the accused to inquisition and obtaining his confession, against the express command of the Japanese Constitution prohibiting the introduction in evidence of a confession made after prolonged detention. ${ }^{87}$ These considerations will lead to the conclusion that release on bail should be granted even before the institution of prosecution.

80 See note 4 supra and accompanying text.

81 See notes 17-23 supra and accompanying text.

82 Dando, Principles of Criminal Procedure 268 (7th ed. 1958). It is illogical to hold that the danger of committing another crime is a reason for refusing release though not for detention itself. It is not equitable to continue the physical restraint of an accused solely because he happened to be arrested.

83 See Foote, supra note 77, at 685.

84 Hirano, Crimtala Procedure 164 (1958); Note, 102 U. Pa. L. Rev. 1077 (1954).

85 See note 31 supra and accompanying text.

80 See note 5 supra and accompanying text.

87 JAPAN, Const. art. 38, para. 2. See Hirano, op. cit. supra note 84, at 150-51. 